\title{
Analysis of Effectiveness of Agricultural Extension Service in among Rural Women: Case study of Odeda Local Government, Ogun State, Nigeria
}

\author{
Ogundiran Oluwasola Adekunle ${ }^{1}$ \\ ${ }^{1}$ Department of Agricultural Economic, Extension and Rural Development. University of Fort Hare. Private Bag \\ X1314, Alice 5700, South Africa \\ Correspondence: Ogundiran Oluwasola Adekunle, University of Fort Hare, Alice, South Africa. Tel: \\ 27-083-570-3601. E-mail: ogundiranoluwasola@yahoo.com
}

Received: June 13, 2013 Accepted: October 12, 2013 Online Published: November 15, 2013

doi:10.5539/jas.v5n12p65 URL: http://dx.doi.org/10.5539/jas.v5n12p65

\begin{abstract}
The study was aimed at determining agricultural extension service in among rural Women, using Odeda local government area of Ogun State as a case study. A sample size of 180 women farmers was initially taken for the study but only data for 160 respondents were analyzed. Simple random sampling technique was used for the sample selection and questionnaire was used to elicit information from the respondents. Both descriptive and inferential statistics were used for data analysis. The findings of this study confirm that women farmers are not a homogeneous group. Despite their valuable contribution in agricultural production, women do not have easy access to agricultural resources, such as the required amount of cultivable land, title of land ownership, improved farm implements. It was also observed that real problems and needs for agricultural advice are not considered on a gender basis when planning and preparing extension packages in the agricultural services. Lack of address of women farmers explicitly as an important clientele group in respective extension programmed activities, the required amount of demonstration materials and equipment for the extension service, lack of appropriate training of field extension agents in extension methodology to serve women farmers and inadequate extension/research linkages are the most important factors which need to be improved to make agricultural extension activities effective in reaching women farmers. It is recommended that Government should encourage and assist women farmers by giving them special attention in terms of access to needed farm inputs.
\end{abstract}

Keywords: agricultural, extension service, rural, women, Nigeria

\section{Introduction}

Agricultural extension still remain one of the most crucial and critical means to reach farming households in the rural areas and globally. The contribution of women to food security in developing countries is extensively documented. Most developing countries, rural women are the basis of small-scale agriculture, the farm labour force and day-to-day family subsistence. Rural women are faced with a number of constraints, they have more difficulties than men in gaining access to land, credit and extension services. There is a need for interventions to improve the economic roles of women have also so far had limited success. Rural women contribute to national agricultural output, save guide the environment and family food security. The involvement of Nigeria women in agriculture has attracted greater attention in recent years (Brown, Feldstein, Haadad, Pena, \& Quisumbing, 2001). The need to develop a suitable extension service that is gender specific and tailored to women farmers cannot be overemphasized. In acknowledgment women play very important roles in Nigeria agricultural production, processing and utilization (Nnadozie \& Ibe, 2000). Women have been making prominent and important contributions to agriculture right from creation and the actually constitute the bulk of the world's food producers. Women in Nigeria engage in various farming activities such as planting, weeding, hoeing, harvesting, threshing and winnowing of agricultural products as well as the processing, storage and marketing of these farm produce.

Majority of these women farmers in Nigeria are also directly involved in the production of some important crops as yams, maize, cassava, groundnut, among others. Similarly a good number of women in rural areas undertake many responsibilities concerning care and management of farm animals like poultry, goats and sheep (Loagun, 1998). During the pre-colonial days, women in Africa cultivated food crops while men hunted and fought wars. Women 
constituted an important live wire of peasant farming distributed all over Nigeria. It is estimated that about $44 \%$ of farm labour in southern states, $45 \%$ in the eastern states, $13 \%$ in the middle belt states and $51 \%$ in the northern states are women (Olaleye, 1998). More so, women in extension are essential for the achievement of some goals such as increased food production, food self-sufficiency and sustained reduction of poverty and malnutrition. Research findings studies indicate that commercialized agricultural regions almost all households have at least one woman who participates in field work, female participation in the regions regarded by traditional agriculture is more in processing activities than in direct field work. Women in these regions have a high participation rate in animal husbandry, which in some areas contributes as much as $30 \%$ of the household income (FAO, 1990).

Meanwhile nationwide adoption of the World Bank support Training and Visit (T and V) as the main approach for extension delivery. Although the system was adopted with distinct home grown modifications, the withdrawal of World Bank funds in the last two decades has proved that the system is not sustainable. While the system is supposed to incorporate feedback from farmers, they are often passive receivers of agricultural information. Like in many other countries where the $\mathrm{T}$ and $\mathrm{V}$ are being implemented, messages are typically based on perceptions of farmers' needs or on the requirements or desires of public sector agencies like the Agricultural Development Programme (ADP) in the case of Nigeria. Studies and critiques have shown that the T and V have not met user demand for appropriate content and appropriate learning methods (Omotayo, 2005). In Nigeria where institutions (Economic and Political) are weak and opportunistic, counterproductive behaviours (Corruption and Cheating) have led to marked increases in transaction costs thus, weakening service delivery (Nnaemeka, 2006). For instance, because of the poor funding, funding instability and the activities of corrupt officials, extension agents, are not paid their salaries for months; materials for field work and transportation facilities, which were formerly provided, are no longer available. Even where they are provided, the materials do not get to the officials. All these have increased the cost of monitoring and dissemination of technology to farmers as government insures additional expenses in order to reach farmers. Since technology improves by the day, numerous approaches have evolved and been applied to ensure valuable broadcasting of extension service to improve the standard of living of Nigeria rural farmers. It was in the cause of this pursuit that it was found that the role of rural women farmers was very important and could not be undermined when targeting an increase in productivity and living standard of the farmers. According to Olawoye (1991), rural women as well as men throughout the world are engaged in a range of productive activities essentials to household welfare, agricultural productivity and economic growth. Agricultural extension strategies traditionally have focus on increasing production of cash crops by providing men with training, information and access to inputs and services. The women contribute the mass of production output for each year in these days. More so, the need to bring the women into the most important or centre of extension service activities so as to ensure increased agricultural productivity.

However, persistent problems of gender discrimination, poverty, inadequate access to land and credit facilities, social cultural factors etc has continually been a bane to the success and implementation of Agricultural Extension service. Women form half of the world and rural area population, and for them to play a more active role in food security, sustainable farming and rural development, there is the need to provide rural women with more qualified, reliable and suitable information continuously and on timely basis (Kizilastan, 2007). For agricultural service and programme to be more successful and effective, effort should be made at creating the right attitude and mind set both with the clientele and the agent. Though, so many factors are responsible for poor dissemination of extension service to women farmers, it is quite expedient to note that the attitude of female farmers might as well be a contributing factor to ineffective delivery of extension service programme. In course of the activities of Women in Agriculture (WIA) unit of OGADEP, OGADEP has introduced several strategic programmes aimed at bringing women farmers into the forefront of agricultural production. It is however, difficult to really specify where the problems of ineffective delivery of agricultural extension services to women farmers lie. The role of women in agricultural and rural development can therefore not be over-emphasized when considering rural and national development of Nigeria.

\section{Problem Statement}

Rural women are actively involved in the process of food production, processing and marketing, social and economic constraints have placed barriers around their access to scientific and technological information from reliable sources (Daman, 1997). Although, researchers have reported that male farmers have more access to agricultural extension services than women in Nigeria. Osuman (1997) observed that agricultural extension services are mostly staffed by men and are inclined to helping men folk. In a study on rural women in food chain activities, Obinne (1995) found that women farm managers have inadequate access to extension services. Since they (women farmers) are engaged in both on-and off-farm activities they do not have time to enjoy the extension service offered. Similarly and Protz (1997) posited that due to the multiple roles women play in the rural household 
(including caretakers of children and the elderly), they do not fully benefit from extension services, particularly, when the time of delivery (of extension service) conflicts with their other household responsibilities. For agricultural service and programme to be more successful and effective in Nigeria and Ogun State in particularly, effort should be made by creating the right attitude and mind set both with the clientele and the agent. Despite the fact that, so many factors are responsible for poor dissemination of extension service to women farmers within this region, it is quite expedient to note that the attitude of female farmers might as well be a contributing factor to ineffective delivery of extension service programme

It is now fully recognised that agricultural extension services suffer from a number of weaknesses in their programmes for rural women. These include: Enable farmers to understand, mitigate and adapt to new climate change challenges; support rural communities to manage their natural resources more effectively; assist farmers to make optimal use of their available resources to ensure access to food and income for their families, lack of education, limited access to credit and inputs, land availability and tenure, lack of suitable farm and household technology, training canters, job availability, inappropriate extension methodology for reaching rural women and lack of proper coordinated implementation of programmes. These problems hinder rural areas especially among women in the rural areas in Nigeria. Therefore it is important to look into the problems without consideration of other issue that are related because aiming to increase the women's income and their Agricultural productivity will succeed if all constraints mention above that facing women can be address (Olawoye, 2010).

Most agricultural countries the issue of socio are very complex, in term of socio-economic socio-cultural and religious factors are need to be analysed and understood for developing effective extension and training programmes to reach women farmers. What is the actual situation and what are the problems and solutions related to effectiveness of agricultural extension programmes for the benefit of women in agricultural countries? What strategies and lines of action can be recommended to governments and external development agencies so that present and future generations of rural women in agricultural countries apply scientific knowledge and use improved agricultural techniques and skills in their farm work? These are questions that need to be answered through this research study.

\section{Objectives of the Study}

The broad objective of this study is to analysis of effectiveness of agricultural extension service in among rural women in the state

\subsection{Specific Objectives}

The following are the specific objectives of the study;

* To build up an existing understanding of women farmers as clientele of the agricultural extension system;

* To determine the competence of the agricultural extension service to provide advisory services to women farmers;

* To determine the constraint of the agricultural extension services in reaching women farmers.

\subsection{Significance of the Study}

There is some evidence to support the contention that women farmer are not being well feed by extension system in Nigeria and failure to reach women farmers is part of major constraint related to resources. The contribution of women to agricultural production over the years has been acknowledged and there is a need to make available to them appropriate extension service to them in order to enhance their productivity. This study will also go a long way in helping government to develop agricultural policy and programmes that will give more attention to the needs of women farmers which shall eventually enhance their agricultural productivity. The important contribution made by women in agriculture justifies the necessity to make the system more equitable. This study will also go a long way in helping government to develop agricultural policy and programmes that will give more attention to the needs of women farmers. The above background, provide the necessary basic and justification for this research study.

\section{Methodology}

Odeda local government area (LGA) is one of the 20 local government areas in Ogun State, Nigeria. The headquarters of the LGA are at Odeda on the on the A5 highway - WikiMiniAtlas $7^{\circ} 13^{\prime} 00^{\prime \prime} \mathrm{N} 3^{\circ} 31^{\prime} 00^{\prime \prime} \mathrm{E} 7.21667$; 3.51667. It has an area of $1,560 \mathrm{~km}^{2}$ and a population of 109,449 at the 2006 census. The Local Government enjoys a tropical climate, with double maxima of rainfall between April and July \{short dry season in August\} and from September to October. The long dry season start from November thus, the land is suitable for agriculture and livestock rearing. Odeda LGA is basically rural, lacking social amenities such as standard medical facilities, good water supply, access roads and schools. The inhabitants of Odeda LGA are mostly farmers and cultivate various 
arable crops such as guinea corn, millet, maize, yam, beans, rice, cassava, oil palm. The population for the study entailed of women farmers in Odeda LGA and a simple random sampling technique was also used to select ten respondents within each of the earlier selected council wards for the study. On the whole, One hundred and sixty women were selected and this constituted the sample size for the study. A questionnaire was designed and used as instrument for primary data collection. Some copies of the questionnaire were given to literate respondents to complete while enumerators were used to assist the illiterate respondents in completing the questionnaire. The women farmers' Socio-economic characteristics considered for the purpose of this study include age, marital status, religion, educational level, income level and farm size. They were measured using the conventional methods. Both descriptive and inferential statistics were used for the analysis of data collected.

\section{Results and Discussion}

\subsection{Demographic and Socio- Economic Characteristic of the Respondents}

The socio-economic characteristic of the respondents examined include, age, marital status of household head, literacy level, farm size, income level these are shown in Table 1 below. It appear that age of the women farmer range from 15-60 years, the women within the age bracket of 30-45 years constituted the highest frequency as 71 people (44.37\%) of women fall into this group. This was followed by those between the ranges of 15-30 years who are 64 people (40.00\%). The respondent between 45-60 years had the lowest frequency of 25 people $(15.63 \%)$. This result show that old women did not really participate on farm activities as much has those between ranges of $15-30$ years. Table 1 also showed that majority of the women farmer in the study area $(85.00 \%)$ were married; $0.63 \%$ was Divorced/separated while 14.37 were widows. The result findings showed that $85 \%$ of the respondents indicate their husband has household head; $15 \%$ household were head by women. Finding revealed that $60 \%$ of the respondents had no education; $15 \%$ respondents had informal education and $24.37 \%$ had primary education. About $18.75 \%$ of the respondent was within low income bracket while $81.25 \%$ were in the average income bracket. The farm size distribution of the respondents shows that $84.38 \%$ of the respondent had large farm size and $15.62 \%$ of the respondent had medium size farms.

Table 1. Socio-economic characteristics of women farmers $\mathrm{N}=160$

\begin{tabular}{lll}
\hline Characteristic & Frequency & Percentages (\%) \\
\hline Age (Years) & 64 & 40.00 \\
$15-30$ & 71 & 44.37 \\
$30-45$ & 25 & 15.63 \\
$45-60$ & & \\
Marital Status & 135 & 85.00 \\
Married & 1 & 0.63 \\
Divorced & 23 & 14.37 \\
Widowed & & \\
Household head Status & & 15.00 \\
Women & 24 & 85.00 \\
Men (husband) & 136 & \\
Education Level & & 60.00 \\
No education & 96 & 15.00 \\
Informal education & 24 & 24.37 \\
Primary level & 40 & 00.00 \\
Secondary level & 0 & \\
Income Level & & 18.75 \\
Low & 30 & 81.25 \\
Average & 130 & \\
Farm size & & 84.38 \\
Large & 135 & 15.62 \\
Medium & 25 & 00.00 \\
Small & 0 & \\
\hline & & \\
\hline & &
\end{tabular}

Source: Field Survey, 2009. 
Table 2. Extension method used and the extend emphasis in relation to women

Source: Field Survey, 2009.

\begin{tabular}{lll}
\hline Method & Male & Female \\
\hline Individual & High & Low \\
Group & Low & High \\
Mass media & Low & Low \\
\hline
\end{tabular}

Table 3. Women farmer gender preference of extension agents

\begin{tabular}{lll}
\hline Gender preference & Frequency & Percentages (\%) \\
\hline Male extension worker & 15 & 9.37 \\
Female extension worker & 110 & 68.75 \\
No gender favourite & 35 & 21.87 \\
\hline
\end{tabular}

Source: Field Survey, 2009.

Table 3 indicates the major issue related to women's convenience to extension advice whether the extension officer who advice women should be male or female, the responds from the women farmer in the study area were indicate in the table 3 above. The result show that $68.75 \%$ of the respondents preferred female extension officers while $9.37 \%$ preferred male extension officers. The major reason given by women famers were because of their low level of education and in most cases male extension officers did not allow them to contribute during the group meetings

\subsection{Challenges Encountered by Women Farmer in Accessing Extension Service}

Table 4 shows that most famous of these challenges was inadequate supply of farm input with $(84.4 \%)$ of the respondents being victim, (75\%) of the respondent indicate financial constraint in purchasing inputs, followed by lack of transportation $(72.5 \%)$, small amount of cultivated land (70.6\%). Others problems in accessing extension service include lack of improved varieties seed (62.5\%), poor communication skill (59.4\%), unavailability of extension agent (56.3\%) lack of cooperation among farmers $(53.7 \%)$ while lack of time to attend extension meeting were $(51.3 \%)$. Among all the problems the least were rift between the farmer and extension agent $(49.4 \%)$.

Table 4. Challenges encountered by women farmer in accessing extension service

\begin{tabular}{lll}
\hline Challenges & Frequency & (\%) \\
\hline Inadequate supply of farm input & 135 & 84.4 \\
Financial constraint in purchasing inputs & 120 & 75.0 \\
Lack of transportation & 116 & 72.5 \\
Small amount of cultivated land & 113 & 70.6 \\
Lack of improved varieties seed & 100 & 62.5 \\
Poor communication skill & 95 & 59.4 \\
Unavailability of extension agent & 90 & 56.3 \\
Lack of cooperation among farmer's & 86 & 53.7 \\
Lack of time to attend the extension meeting & 82 & 51.3 \\
Rift between farmer and extension agent & 79 & 49.4 \\
\hline
\end{tabular}

Source: Field Survey, 2009. 


\subsection{Problem Affecting Agricultural Extension Service to Women in the Study Area}

Table 5. Problem affecting agricultural extension service to woman farmer in the study area

\begin{tabular}{ll}
\hline Problems areas & Rank \\
\hline Lack of technology suitable for women & $3^{\text {rd }}$ \\
Lack of adequate transportation to reach women farmer & $5^{\text {th }}$ \\
Coverage too much area for one agent & $7^{\text {th }}$ \\
Lack of practical agricultural training in improved technology & $6^{\text {th }}$ \\
Lack of demonstration materials & $1^{\text {st }}$ \\
Lack of vital teaching and communication equipment & $2^{\text {nd }}$ \\
Lack of training in extension method and communication skill & $4^{\text {th }}$ \\
Lack of subject matter specialist to service women problems & $8^{\text {th }}$ \\
Lack of provision for women farmer's participation in extension program & $10^{\text {th }}$ \\
Lack of knowledge in understanding problems and needs of women & $9^{\text {th }}$ \\
\hline
\end{tabular}

Source: Field Survey, 2009.

As shown in table 5, lack of demonstration, lack of essential teaching and communication equipment and lack of technology suitable for women were consistently rank as three of the greatest problem in the study area while lack of training in extension method and communication skill, lack of adequate transportation to reach women and lack of practical agricultural training in improved technology were rank $4^{\text {th }}, 5^{\text {th }}$ and $6^{\text {th }}$ respectively. The findings reveal that lack of provision for women farmers participation in extension program was rank the least problem with $10^{\text {th }}$

\section{Conclusion}

The findings presented in this study show those women farmers are not a homogeneous group. They represent different socio-economic situations with different needs for extension contact and the use of extension methods. Women's access to agricultural inputs has not improved proportionately. Therefore, agricultural extension has little or not improved technology to extend to women farmers who grow the traditional food crops. In other cases, technology is available, but women are unable to obtain the credit to purchase the inputs needed to utilize the new technology. The findings in the study revealed that majority of the women were agile and actively involved in Agricultural activities, and that the high level of illiteracy among the respondents was responsible for their negative attitude to extension service. The study also revealed that "Demonstration of improved technologies" and "Distribution of subsidized seeds" were the most factor affecting extension services.

\section{Recommendation}

The extension service should be more gender-sensitive when organizing extension activities, so that women farmers have full and appropriate access to extension meetings, demonstrations, field days and other activities. A proportion of women farmer participants should be targeted in each extension activity that can specially benefit them.

Government should encourage and assist women farmers by giving them special attention in terms of access to needed farm inputs. New farming implements which will reduce drudgery and are affordable should be made available to women farmers.

Extension agents should endeavour to foster better working relationships between themselves and the women farmers as this would grant them more freedom to express their plight and challenges better.

Financial aid should be granted to the women to cushion the effects of financial constraints in accessing extension services and lack of collateral in securing loans. These would also furthermore boost their self-esteem in exploring the benefits of extension service.

\section{References}

Brown, L. R., Feldstein, H., Haadad, L., Pena, C., \& Quisumbing, A. (2001). Women as producer gatekeepers and shock absorbers. In A. Per Pinstrup, \& P. L. Rajul (Eds.), The Unfinished Agenda - Perspectives on over coming Hunger, Poverty and Environmental Degradation. DFID Sustainable livelihoods guidance. 
Daman, P. (1997). Cooperatives and Poverty Reduction: Enhancing Social and Economic Imperatives. ICAROAP, New Delhi, PS.

Ekong, E. (1988). An Introduction to Rural Sociology. Ile-Ife: Jumak Publishers.

FAO. (1990). Report of the Global Consultation on Agricultural Extension, Rome.

Greene, J. C., Caracelli, V. J., \& Graham, W. F. (1989). Toward a Conceptual Framework for mixed-Method valuation Designs. Educational Evaluation and Policy Analysis, 11, 255-274.

Kizilastan, N. (2007). Rural women in Agricultural extension training. Research Journal of Social Science, 2(1), 23.

Loagun, E. U. (1998). Rural Women Training Needs: Preferences for Methods, Place, Duration and Time.

Nnadozie, B., \& Ibe, I. (2000). Women in agriculture: Problems and prospects. In A. C. Nwosu, C. U. Nwajiuba, \& J. A. Mbanasor (Eds.), Agricultural Transformation in Nigeria. Owerri, Imo State: Novelty Industrial Enterprises.

Nnaemeka, A. C., Agwu, A. E., \& Nicholas, O. (2006). Constraints and Strategies towards Effective Cost-sharingof Agricultural Technology Delivery in Nigeria: Perception of Farmers and Agricultural Extension Personnel. J. Intl. Agric. Extension Educ., 13(1), 29-41.

Obinne, C. (1995). Rural Women in food chain Activities: A case of Ibo speaking Ethnic Community of Delta State, Nigeria. Agrores, 1(1), 35-40.

Ogunlela, Y., Aisha, I., \& Mukhtar, A. (2009). Gender Issues in Agriculture and Rural Development in Nigeria: the Role of Women. Humanity \& Social Sciences Journal, 4(1), 19-30.

Olaleye, S. O. (1998). Women in Rural Development. Nigerian Agriculture Magazine, October/November, 32-33.

Olawoye, J. E, Okye, O., \& Eleri, A. (2010). Gender and Climate Change Toolkit for Policy Makers and Programme Developers Nigeria. CAN / C4C / DFID / ICEED, Abuja.

Omotayo, A. M. (2005). I C T and Agricultural Extension: Emerging Issues in Transferring Agricultural Technologies in Developing Countries. In edl Adedoyin, S. F. (Ed.), Agricultural Extension in Nigeria. Agricultural Extension Society of Nigeria.

Osuman, G. I. (1997). The Education of Women in Developing Countries (pp. 55-64). Osuman and Co., Makurdi, Nig.

Protz, M. (1997). Developing Sustainable Agricultural Technologies with Rural Women in Jamaica: A participatory media Approach (pp. 1-3). University of Reading, UK.

Saito, K., \& Gadzame, E. (1996). Nigeria women in Agriculture. World Bank Participation Sourcebook 1996. Retrieved on 23rd March, 2013, from www.worldbank.org/wbi/sourcebook/sbpdf.htm

Yauch, C. A., \& Steudel, H. J. (2003). Organizational Research Methods, 6(4), $465-481$. http://dx.doi.org/10.1177/1094428103257362

\section{Copyrights}

Copyright for this article is retained by the author(s), with first publication rights granted to the journal.

This is an open-access article distributed under the terms and conditions of the Creative Commons Attribution license (http://creativecommons.org/licenses/by/3.0/). 